\title{
Combined Therapy of ATRA and Imatinib Mesylate Decreases BCR-ABL and ABCB1/MDR1 Expression Through Cellular Differentiation in a Chronic Myeloid Leukemia Model
}

\author{
CAMILA ALBUQUERQUE PINTO ${ }^{1}$, ADRHYANN JULLYANNE DE SOUSA PORTILHO ${ }^{2}$, \\ MARITZA CAVALCANTE BARBOSA ${ }^{3}$, MARIA ELISABETE AMARAL DE MORAES ${ }^{2}$, \\ JOSÉ ALEXANDRE RODRIGUES DE LEMOS ${ }^{4}$, \\ ROMMEL MARIO RODRIGUEZ BURBANO ${ }^{1}$ and CAROLINE AQUINO MOREIRA-NUNES ${ }^{2}$ \\ ${ }^{1}$ Human Cytogenetics Laboratory, Biological Science Institute, Federal University of Pará, Belém, Brazil; \\ ${ }^{2}$ Pharmacogenetics Laboratory, Drug Research and Development Center (NPDM), \\ Department of Physiology and Pharmacology, Federal University of Ceará, Fortaleza, Brazil; \\ ${ }^{3}$ Faculty of Pharmacy, Federal University of Ceará, Fortaleza, Brazil; \\ ${ }^{4}$ Biological Science Institute, Federal University of Pará, Belém, Brazil
}

\begin{abstract}
Background/Aim: Chronic Myeloid Leukemia $(C M L)$ is a clonal myeloproliferative disease, and a major challenge for the eradication of CML is to understand the cause of the permanence of minimal residual disease (DRM). This work aimed to induce the maturation of leukemic stem cells with All-trans-retinoic acid (ATRA), making them sensitive to treatment with Imatinib (IM). Materials and Methods: K562 cells were treated with IM and with the combined therapy of ATRA together with IM for 48 and 72 $h$. The expression of $B C R-A B L$ gene and multidrug resistance gene $A B C B 1$ were evaluated using $R T-q P C R$. Results: The combined ATRA and IM therapy showed a discreet cell differentiation pattern, evidenced by the panoptic morphology analysis at 48 and $72 \mathrm{~h}$ of treatment. The BCR-ABL expression showed no statistical difference when treated alone with IM, however in combination with ATRA, the expression was statistically significant in 48 and $72 h(p \leq 0.0001)$ and when the treatment groups were compared to each other $(p \leq 0.001)$. The ABCB1 gene expression showed a decrease in isolated IM therapy
\end{abstract}

This article is freely accessible online.

Correspondence to: Caroline Aquino Moreira-Nunes, Laboratory of Pharmacogenetics, Drug Research and Development Center, Federal University of Ceará, Coronel Nunes de Melo st, n 1000, Rodolfo Teófilo, CEP: 60416-000 Fortaleza, CE, Brazil. Tel: +55 8533668033, e-mail: carolfam@gmail.com

Key Words: Chronic Myeloid Leukemia, Imatinib Mesylate, ATRA, BCR-ABL, MDR. $(p \leq 0.05)$ and in the combination in 48 and $72 h(p \leq 0.0001)$. Conclusion: Combined ATRA and IM therapy was shown to be effective in decreasing $B C R-A B L$ and $A B C B 1$ genes, possibly through the differentiation of blast cells, demonstrating that the therapy could be potentially effective in the blast crisis of the disease and for those patients who develop resistance to available CML treatments.

Chronic myeloid leukemia (CML) is a clonal myeloproliferative disease cytogenetically characterized by the Philadelphia $(\mathrm{Ph}+)$ chromosome, which is the result of a reciprocal translocation between the long arms of chromosomes 9 (9q34) and 22 (22q11) (1, 2). This translocation is responsible for uniting the breakpoint cluster region $(B C R)$ and Abelson leukemia virus (ABL) genes, forming the chimeric $B C R-A B L$ gene in Philadelphia positive $(\mathrm{Ph}+)$ cells. The resulting protein of this chimeric gene is the oncoprotein p210 that has tyrosine kinase activity, which confers an intense proliferative activity and a consequent adaptive advantage to $\mathrm{Ph}+$ cells (3-5).

The first-line drug most used in the treatment of CML is Imatinib Mesylate (IM), a tyrosine kinase inhibitor (TKI). Its mechanism of action consists of inhibiting the chimeric $B C R-A B L$ gene by occupying the ATP binding site, thereby inhibiting the cell signaling cascade that leads to increased cell proliferation, halting cell differentiation and resistance to apoptosis $(6,7)$.

IM induces a complete haematological response in almost all patients in the chronic phase; in patients in the accelerated phase the percentage decreases to $50 \%$ and, in patients who are in the blast phase, the positive response to IM is quite small $(<5 \%)(7,8)$. Despite the effectiveness of IM treatment, 
relapses and resistance to therapy are frequent, mostly due to multiple drug resistance (MDR), which can be found in various cancer cells drastically limiting and complicating the healing effect of drugs for a variety of tumors $(9,10)$.

MDR is considered a multifactorial phenomenon and occurs mainly due to the hyperexpression of ATP binding cassette $(A B C)$ superfamily protein transporters, a large family of proteins that uses the energy of hydrolysis of ATP to expel the active drug from inside the cells (11).

Multidrug Resistant protein 1/ATP Binding Cassette Subfamily B Member $1(M D R 1 / A B C B 1)$ is a carrier that was initially identified in cells related to resistance to multiple drugs and can expel a wide variety of structurally unrelated drugs that enter cells through passive diffusion and, as a result, the drug's intracellular level fails to reach an ideal toxic concentration to become effective (12).

Studies have shown that those resistant cells are part of the undifferentiated compartment of leukemic stem cells (CD34+) (13-15). This demonstrates how challenging it is for therapies involving TKI to eradicate the permanence of minimal residual disease (DRM) and, consequently, to end the cases of disease recurrence $(16,17)$.

All-trans-retinoic acid (ATRA) is a metabolite of retinol and belongs to the class of retinoids. Studies with ATRA in vitro have demonstrated its great potential to induce differentiation and inhibition of cell proliferation in transformed hematopoietic cell lines, including those derived from human myeloid leukemia cells $(18,19)$.

This work aims to circumscribe the resistance of immature hematopoietic stem cells (CD34+) to chemotherapy treatment; we propose to induce the differentiation of these cells with ATRA using the blast cell line model K-562, making these cells mature and sensitive to treatment with IM.

\section{Materials and Methods}

Cell culture. Chronic myeloid leukemia cells K-562 were kindly provided by Professor Vivian M. Rumjanek from the Federal University of Rio de Janeiro, Brazil and maintained in RPMI medium with $10 \%(\mathrm{v} / \mathrm{v})$ fetal bovine serum $\left(\mathrm{Gibco}^{\circledR}\right.$, Carlsbad, CA, USA). All cells were maintained in media with $1 \%(\mathrm{v} / \mathrm{v})$ penicillin $(100 \mathrm{U} / \mathrm{ml})$ and streptomycin $(100 \mathrm{mg} / \mathrm{ml})\left(\mathrm{Gibco}^{\circledR}{ }^{\circledR}\right.$ Carlsbad, CA, USA) and incubated with $5 \% \mathrm{CO}_{2}$ at $37^{\circ} \mathrm{C}$.

Drugs. Imatinib mesylate (IM) and all-trans retinoic acid (ATRA) were purchased from Sigma Aldrich (St Louis, MO, EUA). The stock solutions of ATRA and IM were diluted in culture medium to reach final concentrations ranging between 0.195 and $25.0 \mu \mathrm{g} / \mathrm{m}$, for both drugs. The maximum concentration of DMSO added to the cells was $0.33 \%$.

Cell treatment. K-562 cells were seeded $\left(5 \times 10^{3}\right.$ cells per well) in a 96-well plate and treated with IM or co-treated with ATRA and IM for 48 and 72 h. For IM, the highest concentration tested was 50.6 $\mu \mathrm{M}$ and for ATRA $83.21 \mu \mathrm{M}$.
Panoptic stain. For the evaluation of differentiation pattern and morphological changes after ATRA treatment, with the highest concentration of $83.21 \mu \mathrm{M}$, about $100 \mathrm{ul}\left(5 \times 10^{3}\right.$ cells $)$ of K-562 cells were placed in a cytocentrifuge for 10 minutes at 1,000 rpm with previously cleaned slides. Subsequently, the slides were stained using the Fast Panoptic kit (LaborClin ${ }^{\circledR}$, PR, Brazil), following the manufacturer's manual with modifications. To assess changes in cell morphology, the slides were analyzed and photographed under an optical microscope Evos ${ }^{\circledR}$ XL (Life Technologies, Carlsbad, CA, USA) in $40 \times$ magnification.

Cell cycle progression. To evaluate the cell cycle distribution after ATRA treatment, K-562 cells were seeded at $3 \times 10^{3}$ cells per well in 96-well plate and treated with ATRA at $83.21 \mu \mathrm{M}$, for 48 and 72 $\mathrm{h}$ of exposure. After this procedure, cells were fixated in $80 \%$ ethanol solution for $30 \mathrm{~min}$ at $4^{\circ} \mathrm{C}$ and then incubated with propidium iodide $(50 \mu \mathrm{g} / \mathrm{ml})$ for $30 \mathrm{~min}$. A total of 20,000 cells were evaluated by flow cytometry (BD FACSVerse) and data were analyzed using FlowJoSoftware v.10 (Becton Dickinson, Franklin Lakes, NJ, USA).

Extraction of RNA and reverse transcription to DNA. RNA from the cells was extracted with TRIzol Reagent ${ }^{\circledR}$ (Invitrogen ${ }^{\mathrm{TM}}$, Carlsbad, CA, USA) according to the manufacturer's instructions. From $20 \mathrm{ng}$ of RNA, the cDNA was synthesized using the High-Capacity cDNA Reverse Transcriptase kit (Life Technologies, Carlsbad, CA, USA). The conversion step was performed on a Veriti ${ }^{\circledR}$ thermal cycler (Applied Biosystems ${ }^{\circledR}$, Foster City, CA, USA). After this step, the samples were stored in a freezer at $-20^{\circ} \mathrm{C}$ until further use.

Gene expression analysis by real-time quantitative polymerase chain reaction $(R T-q P C R)$. The genes selected for evaluation were $B C R-A B L 1$ (Hs03024784_ft) and $A B C B 1$ (Hs00184500_m1), while the $A B L$ gene (Hs01104728_m1) was used as an internal control. The detection method was the TaqMan ${ }^{\circledR}$ Gene expression assays (Applied Biosystems ${ }^{\circledR}$, Foster City, CA, USA) and qPCR was performed using QuantStudio5 ${ }^{\circledR}$ Real-Time PCR system (Applied Biosystems ${ }^{\circledR}$, Foster City, CA, USA). For each sample, the following were used: $3 \mu \mathrm{l}$ of cDNA, $1 \mu \mathrm{l}$ of each primer/probe, 12.5 $\mu \mathrm{l}$ of TaqMan ${ }^{\circledR}$ Gene Expression Master Mix (Life Technologies, Carlsbad, CA, USA) and $8.5 \mu \mathrm{I}$ of ultra-pure water. The geneexpression levels were based on relative analyses and calculated using the $2^{-\Delta \Delta C T}$ (delta delta threshold cycle) method (20). Each sample was analyzed in triplicate for experimental validation (21).

Statistical analysis. One-way analysis of variance (ANOVA) was performed to analyze gene-expression data, with a significance level of $5 \%(p<0.05)$. Data were analyzed using the mean and standard deviation of three independent experiments. The Bonferroni correction was used for multiple comparisons.

\section{Results}

The analysis of cell morphology by Panoptic staining showed a discrete pattern of cell differentiation after ATRA treatment, with exposure at the highest tested concentration $(83.21 \mu \mathrm{M})$ after 48 and $72 \mathrm{~h}$ of treatment in K-562 cells (Figure 1A-C). The cells after treatment demonstrated a pattern of cell maturation and differentiation compatible with 

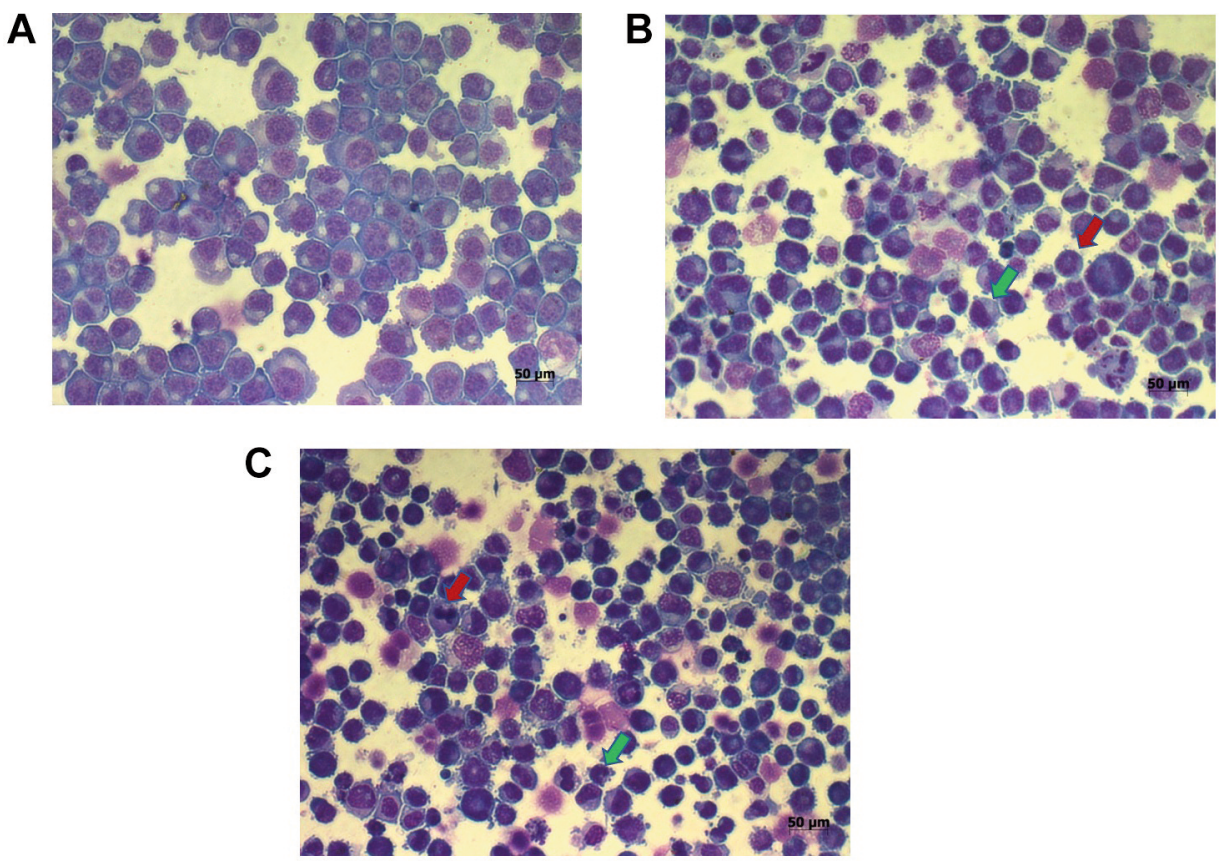

Figure 1. Analysis of cell morphology. (A) K-562 cells without treatment, showing the huge and exclusive population of immature cells of blast origin; (B) K-562 cells after 48 hours of exposure to ATRA treatment, demonstrating a slight differentiation of cell maturation and the presence of myelocytes (red arrow) and metamyelocytes (green arrow); (C) K-562 cells after 72 hours of ATRA exposure presenting a proeminent cell differentiation and the presence of band forms (red arrow) and granulocytes (green arrow).

that seen in the hematopoietic process, showing a slight differentiation of cell maturation and the presence of myelocytes and metamyelocytes after $48 \mathrm{~h}$ of treatment (Figure 1B). The analisys after $72 \mathrm{~h}$ of ATRA and IM exposure, showed a proeminent hematological cell differentiation and the presence of band forms and granulocytes (Figure 1C).

The cell cycle analysis showed a change in pattern distribution of cells after $83.21 \mu \mathrm{M}$ of ATRA exposure, at 48 and $72 \mathrm{~h}$ after treatments indicating that ATRA induced the cell proliferation and differentiation (Figure 2A-C).

The next step was to evaluate the gene expression levels of $B C R-A B L 1$ and $A B C B 1$ genes after cellulartreatment with Imatinib, ATRA and with the combined therapy at the highest concentrations. The $B C R-A B L$ expression showed no statistical difference when treated alone with IM, however in combinationwith ATRA, the expression was statistically decreased in 48 and $72 \mathrm{~h}(p \leq 0.0001)$ and when the treatment groups were compared to each other $(p \leq 0.001)$ (Figure 3).

The $A B C B 1$ gene expression analysis showed a significant decrease in IM therapy alone $(p \leq 0.05)$ and a more significant decrease in the combined therapy of ATRA together with IM in 48 and $72 \mathrm{~h}(p \leq 0.0001)$. This shows that the co-therapy presented a greater inhibition of the $A B C B 1$ gene transcripts (Figure 4).

\section{Discussion}

TKIs targeting the BCR-ABL protein, like IM, have brought a revolutionary change in the CML therapy (22) and although the generation of these TKIs has greatly improved the CML prognosis, a significant portion of patients have a response treatment failure due to resistance to these drugs $(7,23)$.

Our results demonstrated that the combined therapy of ATRA and IM was able to promote hematopoietic differentiation of the granulocytic lineage in K-562 cells, observed in 48 and $72 \mathrm{~h}$ after treatment (Figure 1A-C). The Panoptic stain demonstrated that ATRA may have had an influence on this role, since ATRA causes immature cells to develop into differentiated mature hematologic cells, which might contribute to mitigating the disease. Additionally the cell cycle progression analysis demonstrated that $83.21 \mu \mathrm{M}$ of ATRA also induced a change in the pattern distribution of cells compared to untreated controls (Figure 2A-C).

ATRA, combined with other drugs, is used to treat acute promyelocytic leukemia (LPA), making immature promyelocytes capable of differentiating into mature granulocytes $(24,25)$. Knowing that the main characteristic of leukemias is the presence of highly proliferative immature cells, the ability of ATRA and its derivatives to induce cell differentiation in altered hematopoietic cell lines, such as the 

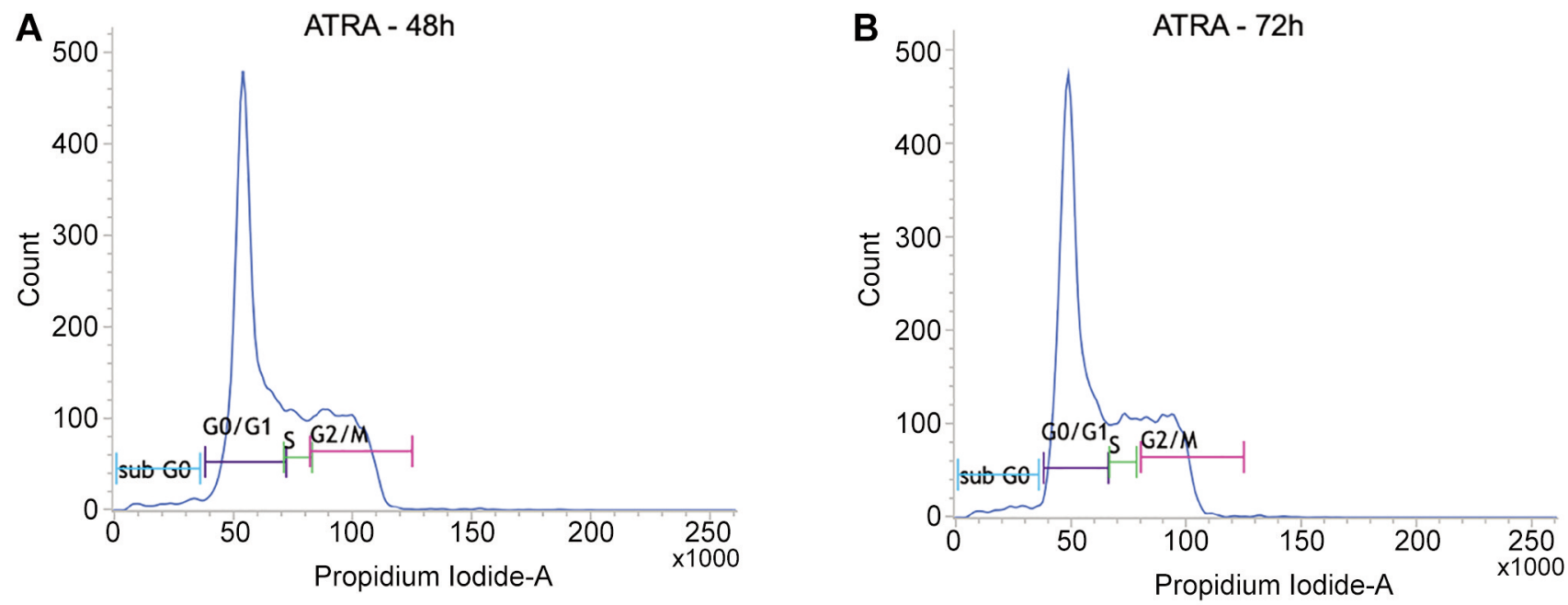

\begin{tabular}{|c|c|c|c|c|}
\hline Group & Sub-G0 & G0/G1 & S & G2/M \\
\hline & Mean \pm SD (\%) & Mean \pm SD (\%) & Mean \pm SD (\%) & Mean \pm SD (\%) \\
\hline Control & $12.42 \pm 0.52$ & $46.49 \pm 1.51$ & $12.63 \pm 1.41$ & $29.64 \pm 3.62$ \\
\hline $48 h$ & $6.56 \pm 1.21$ & $61.57 \pm 1.49$ & $14.72 \pm 0.70$ & $18.80 \pm 1.81$ \\
\hline $\mathbf{7 2 h}$ & $4.16 \pm 0.95$ & $62.52 \pm 1.21$ & $15.51 \pm 1.76$ & $12.24 \pm 1.90$ \\
\hline
\end{tabular}

Figure 2. Cellular effects of $83.21 \mu M$ ATRA treatment in the leukemia cell line $K$-562. Graph represents the cell cycle distribution after ATRA exposure for (A) $48 \mathrm{~h}$ and $(B) 72 \mathrm{~h}$. (C) Table represents the mean $\pm S D$ of the percentage of cells in $S u b-G 1, G_{0} / G_{1}, S$ and $G_{2} / M$ phase upon exposure to $83.21 \mu M$ ATRA.

K-562 line, has been explored in several studies $(26,27)$. Previous studies have proven that pharmacological induction with ATRA was able to promote phenotypic changes of the K562 lineage in differentiated cells from the granulocytic and erythroid hematopoietic lineages $(28,29)$.

In this work, the results referring to the analysis of the gene expression of $B C R-A B L 1$ transcripts were also positively affected by the combined treatment, which significantly demonstrated a decrease in expression levels in 48 and $72 \mathrm{~h}(p<0.0001)$ and with an increase in inhibitory potency after $72 \mathrm{~h}$ when treatment times were compared $(p<0.001)$. In myeloid strains previously resistant to TKI, ATRA blocked the acquisition of $B C R-A B L$ mutations and resistance to TKI $(30,31)$. In a recent study, a CML patient who progressed to a promyelocytic blast crisis treated with ATRA and arsenic trioxide achieved complete morphological remission (32).

Additionally, a study previously carried out by our research group showed that the expression of $B C R-A B L 1$ levels between leukemic cell lines, including K-562, and patients with CML was similar. This validates the use of these cell lines as an indispensable tool for the knowledge of the particularities related to the development, differentiation, and susceptibility to the treatment of tumor cells (33).

After the induction of ATRA and IM co-therapy, we evaluated the $M D R / A B C B 1$ gene expression. The data demonstrated that the combined therapy was able to significantly decrease expression levels at 48 and $72 \mathrm{~h}$ after treatment $(p<0.0001)$, showing an important molecular effect in blocking the MDR phenotype. MDR mediated by members of the ABC superfamily has therefore become one of the greatest obstacles to overcoming tumor progression and the overexpression of these proteins results in an increase in the resistance of cancer cells to chemotherapy, which can be a determining factor for patients' non-response to antineoplastic treatments (34).

The acquisition of resistance to chemotherapy treatments in cancer patients is a major clinical problem and remains a critical obstacle in antineoplastic treatment and, therefore, the elucidation of the molecular mechanisms underlying the MDR phenotype is important to identify possible targets in human cancers (9). 


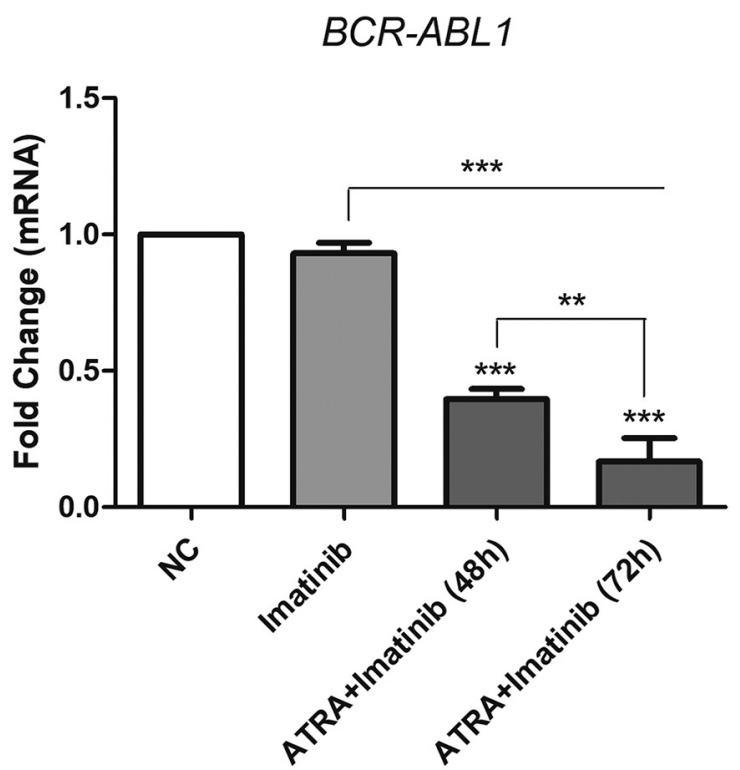

Figure 3. Evaluation of breakpoint cluster region - Abelson murine leukemia $(B C R-A B L 1)$ gene expression in the $K-562$ cell line after treatment with IM alone or ATRA together with IM at the highest tested concentrations. Fold change data are represented as mean \pm standard deviation of three independent experiments. BCR-ABL gene expression was compared between the leukemia cell line $K-562$, relative to that in $M R C-5$ lung fibroblasts, using ANOVA with Bonferroni correction. $* * p<0.001$ and $* * * p<0.0001$. NC: Negative control.

Moreira-Nunes et al. reported that there is a greater presence of drug influx and an absence of efflux channels in mature granulocytic cells (CD66b+) from CML patients and thus, mature cells tend to respond better to treatment with Imatinib. In contrast, stem cells (CD34+) showed a decrease in influx channels and an increased presence of drug efflux channels that are widely known in the literature as agents that cause resistance to chemotherapy. This may be the answer to why CD34+ cells are insensitive to IM treatment (17).

The data presented here emphasize the need and importance of further studies on hematopoietic progenitors' cell differentiation and their role in therapeutic efficiency in patients with refractory leukemia with resistance to therapies available and persistence of DRM.

\section{Conclusion}

Combined ATRA and IM therapy has been shown to be effective in decreasing the expression of the $B C R-A B L$ gene, possibly through the differentiation of blast cells, making them the target of IM therapy. In addition, the data demonstrated that the combination ATRA and IM also favors the decrease of the $A B C B 1$ molecular chemoresistance mechanism,

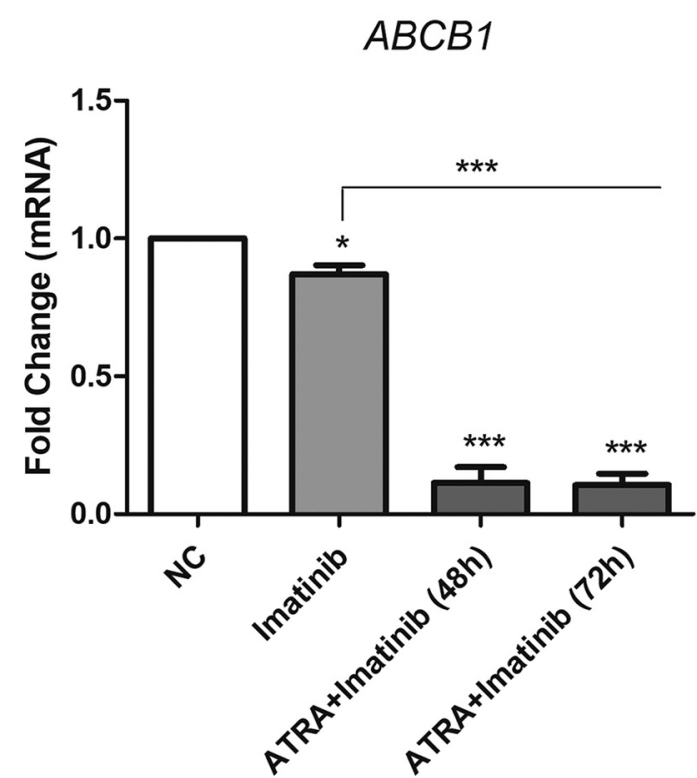

Figure 4. Evaluation of ATP Binding Cassette Subfamily B Member 1 (ABCB1) gene expression in K-562 cells after IM alone or ATRA and $I M$ treatment at the highest tested concentrations. Fold change data are represented as mean \pm standard deviation of three independent experiments. ABCBI gene expression was compared between the leukemia cell line $K-562$ relative to the MRC-5 cell line, using ANOVA with Bonferroni correction. $* p<0.05$ and $* * * p<0.0001$. NC: Negative control.

demonstrating that the therapy could be potentially effective in the blast crisis of the disease and for those patients who develop resistance to available CML treatments.

\section{Conflicts of Interest}

The Authors declare no conflicts of interest regarding this study.

\section{Authors' Contributions}

Lemos JAR and Moreira-Nunes CA, performed the study design; Pinto CA, Barbosa MC, Portilho AJS, and Moreira-Nunes CA, performed the cell culture analysis; Pinto CA, and Moreira-Nunes CA performed the molecular and statistical analysis; Pinto CA, RMRB, Moraes MEA, and Moreira-Nunes CA wrote the article. All Authors read and approved the final article.

\section{Acknowledgements}

The Authors would like to thank the Multi-User Facility of Drug Research and Development Center of the Federal University of Ceará for technical support. This study was supported by Brazilian funding agencies of the National Counsel of Technological and Scientific Development (CNPq; to Burbano RMR, Moraes MEA and Moreira-Nunes CA) and Amazon Foundation for Support Studies and Research (FAPESPA, \#122/2014 to Moreira-Nunes CA). 


\section{References}

1 Nowell PC: The minute chromosome (Phl) in chronic granulocytic leukemia. Blut 8: 65-66, 1962. PMID: 14480647. DOI: $10.1007 / \mathrm{BF} 01630378$

2 Rowley JD: Letter: A new consistent chromosomal abnormality in chronic myelogenous leukaemia identified by quinacrine fluorescence and Giemsa staining. Nature 243(5405): 290-293, 1973. PMID: 4126434. DOI: $10.1038 / 243290 a 0$

3 Faderl S, Talpaz M, Estrov Z, O'Brien S, Kurzrock R and Kantarjian HM: The biology of chronic myeloid leukemia. N Engl J Med 341(3): 164-172, 1999. PMID: 10403855. DOI: 10.1056/NEJM199907153410306

4 Sawyers CL: Chronic myeloid leukemia. N Engl J Med 340(17): 1330-1340, 1999. PMID: 10219069. DOI: 10.1056/ NEJM199904293401706

5 Houshmand M, Simonetti G, Circosta P, Gaidano V, Cignetti A, Martinelli G, Saglio G and Gale RP: Chronic myeloid leukemia stem cells. Leukemia 33(7): 1543-1556, 2019. PMID: 31127148. DOI: 10.1038/s41375-019-0490-0

6 Kantarjian H, Sawyers C, Hochhaus A, Guilhot F, Schiffer C, Gambacorti-Passerini C, Niederwieser D, Resta D, Capdeville R, Zoellner U, Talpaz M, Druker B, Goldman J, O'Brien SG, Russell N, Fischer T, Ottmann O, Cony-Makhoul P, Facon T, Stone R, Miller C, Tallman M, Brown R, Schuster M, Loughran T, Gratwohl A, Mandelli F, Saglio G, Lazzarino M, Russo D, Baccarani M, Morra E and International STI571 CML Study Group: Hematologic and cytogenetic responses to imatinib mesylate in chronic myelogenous leukemia. N Engl J Med 346(9): 645-652, 2002. PMID: 11870241. DOI: 10.1056/ NEJMoa011573

7 Hochhaus A, Baccarani M, Silver RT, Schiffer C, Apperley JF, Cervantes F, Clark RE, Cortes JE, Deininger MW, Guilhot F, Hjorth-Hansen H, Hughes TP, Janssen JJWM, Kantarjian HM, Kim DW, Larson RA, Lipton JH, Mahon FX, Mayer J, Nicolini F, Niederwieser D, Pane F, Radich JP, Rea D, Richter J, Rosti G, Rousselot P, Saglio G, Saußele S, Soverini S, Steegmann JL, Turkina A, Zaritskey A and Hehlmann R: European LeukemiaNet 2020 recommendations for treating chronic myeloid leukemia. Leukemia 34(4): 966-984, 2020. PMID: 32127639. DOI: 10.1038/s41375-020-0776-2

8 Bonifacio M, Stagno F, Scaffidi L, Krampera M and Di Raimondo F: Management of chronic myeloid leukemia in advanced phase. Front Oncol 9: 1132, 2019. PMID: 31709190. DOI: $10.3389 /$ fonc. 2019.01132

9 Chen JR, Jia XH, Wang H, Yi YJ and Li YJ: With no interaction, knockdown of Apollon and MDR1 reverse the multidrug resistance of human chronic myelogenous leukemia K562/ADM cells. Oncol Rep 37(5): 2735-2742, 2017. PMID: 28358418. DOI: $10.3892 /$ or.2017.5535

10 Zhang M, Jing S, Zhang J, Zhang J, Zang X, Qiao M, Zhao X, $\mathrm{Hu} \mathrm{H}$ and Chen D: Intracellular release of PluronicL64 unimers into MCF-7/ADR cells to overcome multidrug resistance by surface-modified PAMAM. J Mater Chem B 5(21): 3970-3981, 2017. PMID: 32264258. DOI: $10.1039 / \mathrm{c} 7$ tb00659d

11 Arrigoni E, Galimberti S, Petrini M, Danesi R and Di Paolo A: ATP-binding cassette transmembrane transporters and their epigenetic control in cancer: an overview. Expert Opin Drug Metab Toxicol 12(12): 1419-1432, 2016. PMID: 27459275. DOI: $10.1080 / 17425255.2016 .1215423$
12 Schmitt SM, Stefan K and Wiese M: Pyrrolopyrimidine derivatives as novel inhibitors of multidrug resistance-associated protein 1 (MRP1, ABCC1). J Med Chem 59(7): 3018-3033, 2016. PMID: 26943020. DOI: 10.1021/acs.jmedchem.5b01644

13 Bhatia R, Holtz M, Niu N, Gray R, Snyder DS, Sawyers CL, Arber DA, Slovak ML and Forman SJ: Persistence of malignant hematopoietic progenitors in chronic myelogenous leukemia patients in complete cytogenetic remission following imatinib mesylate treatment. Blood 101(12): 4701-4707, 2003. PMID: 12576334. DOI: 10.1182/blood-2002-09-2780

14 Michor F, Hughes TP, Iwasa Y, Branford S, Shah NP, Sawyers CL and Nowak MA: Dynamics of chronic myeloid leukaemia. Nature 435(7046): 1267-1270, 2005. PMID: 15988530. DOI: 10.1038/nature03669

15 Prieto-Vila M, Takahashi RU, Usuba W, Kohama I and Ochiya T: Drug resistance driven by cancer stem cells and their niche. Int J Mol Sci 18(12): 2574, 2017. PMID: 29194401. DOI: 10.3390/ijms 18122574

16 Arrigoni E, Del Re M, Galimberti S, Restante G, Rofi E, Crucitta S, Baratè C, Petrini M, Danesi R and Di Paolo A: Concise review: Chronic myeloid leukemia: Stem cell niche and response to pharmacologic treatment. Stem Cells Transl Med 7(3): 305314, 2018. PMID: 29418079. DOI: 10.1002/sctm.17-0175

17 Moreira-nunes C, Azevedo T, Beltrão A, Francês L, Sousa R, Silva I, Silva A, Silva W and Lemos J: Differentially expressed genes responsible for insensitivity of CD34+ cells to kinase inhibitors in patients with chronic myeloid leukemia. BMC Proceedings 7(S2), 2020. DOI: 10.1186/1753-6561-7-S2-O1

18 Nowak D, Stewart D and Koeffler HP: Differentiation therapy of leukemia: 3 decades of development. Blood 113(16): 36553665, 2009. PMID: 19221035. DOI: 10.1182/blood-2009-01198911

19 Madan V and Koeffler HP: Differentiation therapy of myeloid leukemia: four decades of development. Haematologica 106(1): 26-38, 2021. PMID: 33054125. DOI: 10.3324/haematol. 2020.262121

20 Schmittgen TD and Livak KJ: Analyzing real-time PCR data by the comparative C(T) method. Nat Protoc 3(6): 1101-1108, 2008. PMID: 18546601. DOI: 10.1038/nprot.2008.73

21 Bustin SA, Benes V, Garson JA, Hellemans J, Huggett J, Kubista M, Mueller R, Nolan T, Pfaffl MW, Shipley GL, Vandesompele $\mathrm{J}$ and Wittwer CT: The MIQE guidelines: minimum information for publication of quantitative real-time PCR experiments. Clin Chem 55(4): 611-622, 2009. PMID: 19246619. DOI: 10.1373/ clinchem.2008.112797

22 Sweet K and Pinilla-Ibarz J: Early switch in tyrosine kinase inhibitor therapy for patients with chronic myeloid leukemia: An emerging clinical question. Crit Rev Oncol Hematol 103: 99108, 2016. PMID: 27262540. DOI: 10.1016/j.critrevonc. 2016.05.009

23 Thompson PA, Kantarjian HM and Cortes JE: Diagnosis and treatment of chronic myeloid leukemia in 2015. Mayo Clin Proc 90(10): 1440-1454, 2015. PMID: 26434969. DOI: 10.1016/ j.mayocp.2015.08.010

24 Huang ME, Ye YC, Chen SR, Chai JR, Lu JX, Zhoa L, Gu LJ and Wang ZY: Use of all-trans retinoic acid in the treatment of acute promyelocytic leukemia. Blood 72(2): 567-572, 1988. PMID: 3165295.

25 Castaigne S, Chomienne C, Daniel MT, Ballerini P, Berger R, Fenaux P and Degos L: All-trans retinoic acid as a differentiation 
therapy for acute promyelocytic leukemia. I. Clinical results. Blood 76(9): 1704-1709, 1990. PMID: 2224119.

26 Koc A, Ozkan T, Hekmatshoar Y, Gurkan-Alp AS, Aktan F, Buyukbingol Z, Sunguroglu A, Buyukbingol E and Karabay AZ: Apoptotic effects of some tetrahydronaphthalene derivatives on K562 human chronic myelogenous leukemia cell line. Anticancer Agents Med Chem 17(14): 1924-1930, 2018. PMID: 28403785. DOI: $10.2174 / 1871521409666170412122811$

27 Li G, Wang K, Li Y, Ruan J, Wang C, Qian Y, Zu S, Dai B, Meng Y, Zhou R, Ge J and Chen F: Role of eIF3a in 4-amino2-trifluoromethyl-phenyl retinate-induced cell differentiation in human chronic myeloid leukemia K562 cells. Gene 683: 195209, 2019. PMID: 30340049. DOI: 10.1016/j.gene.2018.10.035

28 Cortesi R, Gui V, Osti F, Nastruzzi C and Gambari R: Human leukemic K562 cells treated with cytosine arabinoside: enhancement of erythroid differentiation by retinoic acid and retinol. Eur J Haematol 61(5): 295-301, 1998. PMID: 9855243. DOI: $10.1111 / j .1600-0609.1998 . t b 01091 . x$

29 Sun L, Liao G, Gao J, Chen TT, Pan LL and Yuan LX: [Expression of mitochondrial ferritin in K562 leukemic cell during ATRA-induced cell differentiation]. Sichuan Da Xue Xue Bao Yi Xue Ban 41(1): 77-80, 90, 2010. PMID: 20369475.

30 Wang Z, Liu Z, Wu X, Chu S, Wang J, Yuan H, Roth M, Yuan $\mathrm{YC}$, Bhatia $\mathrm{R}$ and Chen $\mathrm{W}$ : ATRA-induced cellular differentiation and CD38 expression inhibits acquisition of BCRABL mutations for CML acquired resistance. PLoS Genet 10(6): e1004414, 2014. PMID: 24967705. DOI: 10.1371/journal. pgen.1004414
31 Huang ME, Ye YC, Chen SR, Chai JR, Lu JX, Zhoa L, Gu LJ and Wang ZY: Use of all-trans retinoic acid in the treatment of acute promyelocytic leukemia. Blood 72(2): 567-572, 1988. PMID: 3165295.

32 Colvin T, Vachhani P, Sait S, Neppalli V and Wang E: All-transretinoic-acid and arsenic trioxide induced remission in promyelocytic blast crisis. Leukemia Research Reports 10: 1619, 2019. DOI: 10.1016/j.lrr.2018.07.002

33 DE Oliveira Sales L, Mesquita FP, DE Sousa Portilho AJ, DE Moraes Filho MO, DE Moraes MEA, Montenegro RC and Moreira-Nunes CA: Comparison of $B C R-A B L$ transcript variants between patients with chronic myeloid leukaemia and leukaemia cell lines. In Vivo 33(4): 1119-1124, 2019. PMID: 31280200. DOI: 10.21873 /invivo.11581

34 Kryczka J and Boncela J: Cell migration related to MDRAnother impediment to effective chemotherapy? Molecules 23(2): 331, 2018. PMID: 29401721. DOI: 10.3390/ molecules 23020331
Received May 6, 2021

Revised May 31, 2021

Accepted June 2, 2021 